\title{
Agroecology Development in Eastern Europe-Cases in Czech Republic, Bulgaria, Hungary, Poland, Romania, and Slovakia
}

\author{
Jan Moudrý Jr. ${ }^{1, *}$, Jaroslav Bernas ${ }^{1}$, Jan Moudrý sr. ${ }^{1}$, Petr Konvalina ${ }^{1}$, Apolka Ujj ${ }^{2}$, \\ Ivan Manolov ${ }^{3}$, Atanaska Stoeva ${ }^{3}$, Ewa Rembiałkowska ${ }^{4}$, Jarosław Stalenga ${ }^{5}$, Ion Toncea ${ }^{6}$, \\ Avram Fitiu ${ }^{7}$, Daniel Bucur ${ }^{8}$, Magdalena Lacko-Bartošová ${ }^{9}$ and Milan Macák ${ }^{9}$ \\ 1 Faculty of Agriculture, University of South Bohemia in Ceske Budejovice, Studentska 1668, \\ 37005 Ceske Budejovice, Czech Republic; bernas@zf.jcu.cz (J.B.); moudry@zf.jcu.cz (J.M.s.); \\ konvalina@zf.jcu.cz (P.K.) \\ 2 Faculty of Agricultural and Environmental Sciences, Szent István University Gödöllö, Páter Károly u. 1, \\ H-2100 Gödöllö, Hungary; Ujj.Apolka@mkk.szie.hu \\ 3 Faculty of Agronomy, Agricultural University Plovdiv, Mendeleev Blvd. 12, 4000 Plovdiv, Bulgaria; \\ manolov_ig@yahoo.com (I.M.); astoeva@au-plovdiv.bg (A.S.) \\ 4 Faculty of Human Nutrition and Consumer Sciences, Warsaw University of Life Sciences, \\ Nowoursynowska 159 C, 02-787 Warsaw, Poland; ewa_rembialkowska@sggw.pl \\ 5 Department of Systems and Economics of Crop Production, Institute of Soil Science and Plant Cultivation, \\ State Research Institute, ul. Czartoryskich 8, 24-100 Puławy, Poland; stalenga@iung.pulawy.pl \\ 6 National Agricultural Research Institute Fundulea, Innovation and Technical Assistance Centre for \\ Ecological Agriculture, Nicolae Titulescu 1, 915200 Fundulea, Romania; toncea@ricic.ro \\ 7 Agricultural Faculty, University of Agricultural Sciences and Veterinary Medicine Cluj-Napoca, \\ CaleaManastur 3-5, 400372 Cluj-Napoca, Romania; afitiu@yahoo.com \\ 8 Faculty of Agriculture, Ion Ionescu de la Brad University of Agricultural Sciences and Veterinary Medicine \\ of Iasi, Aleea Mihail Sadoveanu 3, 700490 Iasi, Romania; dbucur@uaiasi.ro \\ 9 Faculty of Agrobiology and Food Resources, Slovak University of Agriculture in Nitra, Tr A. Hlinku 2, \\ 94976 Nitra, Slovakia; magdalena.lacko-bartosova@uniag.sk (M.L.-B.); milan.macak@uniag.sk (M.M.) \\ * Correspondence: jmoudry@zf.jcu.cz; Tel.: +420-387-772-456
}

Received: 16 March 2018; Accepted: 20 April 2018; Published: 24 April 2018

\begin{abstract}
Agroecology is a discipline of science that is based on several disciplines, primarily ecology and agronomy. Although the first mention of agroecology was more than 100 years ago, it has recently been more intensely developed throughout Eastern European countries, beginning in the 1990s. Basically, such interest developed due to the intensification of agriculture in the second half of the 20th century, which was based on the premise of agricultural research, and related specifically to production. Agroecology is also strongly associated with sustainable agricultural activities, especially organic farming, which began to develop in Eastern European countries around 1990. Due to the unique environment of Eastern European countries, and a combination of several disciplines within them as well as other factors, agroecology in these differing countries can be perceived as somewhat different from one another. This overview focuses on the current state of agroecology in the Czech Republic, Poland, Hungary, Bulgaria, Romania, and Slovakia.
\end{abstract}

Keywords: agroecology; Eastern Europe; organic farming; development

\section{Agroecology as a Scientific Discipline}

Agroecology stands at the interface of several disciplines, its name being based on two fundamental disciplines: ecology and agronomy. The primary focus of ecology is on natural systems, 
while the focus of agronomy lies in the research and application of scientific knowledge relevant to agricultural practice [1-4]. Agroecology focuses on research into the use and functioning of fields and generally farmed ecosystems. Agroecology is the holistic study of agroecosystems, including all of their environmental and human elements [5]. It deals with relationships among plants, animals, microorganisms, and agricultural soil, as well as its relationships to these organisms in the landscape [6]; it also evaluates the impact of agrotechnology on the ecosystems of farmed land. The main objective is to optimize farm and landscape management practices [7]. Different definitions originate from one common root, which everyone agrees upon: sustainability is a global strategy to preserve the world, including the conscious use of resources that can satisfy the current generation's needs in a way that does not diminish the next generation's chances [8-12]. This definition also implies that in the course of agricultural production, reasonable management of natural resources is needed while balancing economic and environmental sustainability. Furthermore, the preservation of the environmental quality has to be considered while producing healthy foods for the modern, conscious society $[13,14]$. In general, it can be stated that the primary user and converter of the natural landscape is agriculture itself; therefore, the protection of nature should be harmonized with agricultural activities [15]. Conversely it is also true that the success of agricultural activity, especially its efficiency, is determined by the natural conditions, i.e., the existence and the condition of natural resources [16]. With this knowledge in mind, it can be stated that compliance with the basic objectives of sustainability does not seem to be complicated, even though it is not easy to judge which production systems and methods are 'appropriate'. Traditional agricultural systems, such as those identified as Globally Important Agricultural Heritage Systems (GIAHS), offer a wealth of knowledge, principles, practices, and biodiversity that cannot be replaced by modern science [17]. Several approaches, including integrated pest management, a polycultural farming system, conservation agriculture, and agroecology combine traditional agriculture practices with modern science [17].

Although the first works indicating the complexity of interactions in agroecosystems come from the first decade of the 20th century, in general, efforts to practically solve problems in agriculture related to ecological and environmental issues have overtaken research in many cases. This can be traced, for example, to the organic farming movement [18], which began to develop after the First World War. In the German-speaking countries, natural farming is emerging, returning to a more rigorous application of biological knowledge in agricultural practice.

Soon after that, biodynamic agriculture, with its starting point being the anthropophysical image of man and nature, was introduced in the 1920s in the R. Steiner Agriculture Course [19,20]. Of these practicable forms of farming, where the ecological approach was obvious, other systems developed and became the basis of current organic farming. Although we can label some of the elements in some of the first systems as unscientific, the current organic farming system can already draw on new findings from agroecological research, and has a number of specialized research centers building on the methodology and results of agroecology. However, if we return to the development of the first ecological systems, then the originally more isolated ecology and agrochemistry sciences, one of which was focused more on theoretical questions and nature, and the other on applied approaches and human beings, have begun to find a common path since the 1920s, with the development of plant ecology, including the cultivated ones [1]. From the scientific circles dealing with these problems, we can hear the terms of ecology in agriculture or agroecology. If we follow the development of these two scientific disciplines just after the Second World War, then ecology continued in its scientific direction, while in agronomy we observed a number of applied approaches that, to a greater extent, influenced not only our own productivity of agroecosystems, but also the individual components of the environment. We can mention, for example, new mechanization or the development of the use of agrochemicals [21]. In this environment, there is once again the intermingling of the interests of individual scientific disciplines that encounter each other in plant ecology, and we can again encounter the names of agricultural ecology or agroecology. The scope of this new scientific discipline has been gradually expanding, with the development of population ecology, an ecosystem approach, or the development of environmental 
protection research. The environmental movement in the 1960s, when humanity began to become more aware of the problems of environmental contamination, with the effects on health and nature, was heavily influenced by the book Silent Spring [22]. Agroecology at that time also began to attract attention at a number of scientific conferences, such as for example, at the first International Organic Congress in 1974, the Report on Agroecosystems Analysis was built [1,23]. From the 1970s, we can talk about both the increased interest of ecologists in the study of agricultural systems as well as the efforts of agricultural experts to extend their research by ecological and environmental approaches [24-26]. It is also the period in which the first monographs titled Agroecology are published, see Gliessman and Wezel et al. $[27,28]$. Contemporary agroecology has thus gradually developed a number of theoretical schools in the world, and in practice, it helps to develop agricultural systems to meet the principles of long-term sustainability, as presented in its definition in 1993 by FAO-UNESCO. It is a system for protecting and preserving soil, water, plant, and animal genetic resources; it dedicated to not degrading the environment, and its mechanisms and processes must be manageable, economically self-sufficient, and socially acceptable [1].

\section{Agroecology in Selected Eastern European Countries}

\subsection{Agroecology in the Czech Republic and Slovakia}

From a historical point of view, between 1918 and 1992, the Czech and Slovak republics formed one state unit (Czechoslovakia); consequently, the issue of agroecology in this review is evaluated for both states within one chapter. In the Czech Republic, agroecology can be described as an area that has seen relatively significant growth, especially after 1989, in connection with the development of the organic farming sector. By analogy with the definition of ecology, we can define agroecology as a doctrine of interactions between economically significant organisms and their environment. Agroecology thus studies agriculture, including forestry, from the point of view of ecology. Agriculture is not only seen as production; the criteria for the functioning of agricultural systems include sustainability, food security, economic viability, the conservation of resources, and social acceptability. Therefore, initiatives and projects supporting changes in agricultural practices and education, supported by individual ministries (Ministry of Agriculture, Ministry for Regional Development, Ministry of the Environment, Ministry of Education, Youth and Sports), research organizations, and farmers themselves, exist today. Agroecology, as a practice, motivates farmers to become part of an environmentally-friendly system (with increased emphasis e.g., on correct crop rotation, composting, soil protection, increasing biodiversity, using alternative sources, etc.). However, environmental management tools are not exclusively covered by the organic farming sector, but have rather become part of subsidies that are also used by conventional agriculture entities. Nevertheless, the agroecology in the Czech Republic is mainly related to the principles of organic farming, which originated in this country from 1990, when the foundations of the whole system were laid with the cooperation of the Ministry of Agriculture of the Czech Republic, the Libera Association, and the PRO-BIO Association (associations of organic farmers). A fundamental shift in the development of organic farming as well as agroecology itself was the year 1990, when the first funds were released to support the emergence of organic farms. Subsidies have been provided up to 1992, and have been apparently the main reason for the increase in areas to about 15,000 ha. The decision of the Ministry of Agriculture of the Czech Republic to cancel subsidies caused the stagnation of areas in the period between 1993-1996, but at the same time, it had a positive influence on the qualitative development of organic farming. A number of organic farms have only ceased their activities because of subsidies. In 1998, financial support for organic farmers was renewed in the Czech Republic. In 1994, it was decided to introduce a single trademark for organic food, especially for marketing reasons and the public visibility of production. International aid was also of great importance for the promotion and support of organic farming. This was a methodical support of a worldwide movement of organic farmers, which included financial and educational support, book publishing, information systems for organic farming etc. Today, organic farming in the 
Czech Republic is a stabilized agricultural system that is supported by the state, and is also the most important area for agroecology development from an area perspective.

Agroecology as a field of science has also been developed in the Czech Republic (former Czechoslovakia) through a number of educational and professional publications on agricultural production, ecology, plant protection, landscape assessment, and also publications bearing the name agroecology itself (see Table 1). Research and education in agroecology began after 1960 at the Faculty of Agronomy, Agricultural University in Nitra, within Czechoslovakia, and the Complex Agricultural Research Station (CARS) in Michalovce (since 1965), which is located in the East Slovak Lowland. CARS was a predecessor of The Research Institute of Agroecology in Michalovce. In the field of education and research, Slovakia has a tradition in the development of agroecology within local universities and research centers. It houses Slovak Agricultural University in Nitra, which has a Faculty of Agrobiology and Food Resources and agroecology within the study programme (first and second cycle, BC and MSc levels); there is also the University of Prešov Faculty of Humanities and Natural Sciences' Department of Ecology, which has a course on agroecology; there are also research institutions, such as the above-mentioned Research Institute of Agroecology in Michalovce and a research institute dedicated to plant production in Piešt'any. The research and teaching of some particular aspects of agroecology in the sense of the application of ecological principles to agricultural systems and their practices is broadly carried out only at the Slovak University of Agriculture in Nitra and in the research institutes for crop and animal production. According to the academic distinctions of the various approaches to agroecology made by Buttel [29], the relevant initiatives in Slovakia belong mainly to the category of agronomic ecology. The basic approach in this branch is derived mostly from agronomy, including the traditional agricultural production sciences.

In both states, which have now been independent for more than 15 years, some non-governmental organizations (NGOs) have been working as agents of agroecological principles. In Slovakia, for example, one of these is a civil association called CEPTA, otherwise known as the Centre for Sustainable Alternatives. The civil association CEPTA was founded in 2005 as an association of people who engage in different activities such as environmental protection, nature protection, support of civil participation, healthy lifestyles, and sustainable alternatives to present consumer lifestyles. The main activities and campaigns of this association include: the greening of traditional agriculture and rural development; the reduction of pesticides in food and the environment, and increases in food security; the support of local and regional production-consumption chains and direct selling; the development of waste production prevention and the creation of a sustainable economic environment for the separation, recycling, and recovery of waste; air quality protection, such as soot removal from urbanized environments; negative effects elimination from intensive biofuels production; the development of cultural and educational activities and free time activities for young people; and the promotion of sustainable economics off the back end of nuclear power.

In the Czech Republic, universities serve as carriers of agroecological principles and environmental education tools for the general public. Agroecology is taught as a field of study at the University of South Bohemia, through the Faculty of Agriculture, and at Mendel University in Brno, through the Faculty of AgriSciences. Practical agroecological approaches include more points of view, not just the ecological basis applied to the agricultural system. In this developed and sophisticated discipline, there is also an environmental and socially sensitive approach to agriculture. The principle of agroecology in the Czech Republic and Slovakia is based, among other things, on the premise that natural ecosystems are a model for long-term sustainable farming systems and on the intention to cooperate with nature. The significant growth of agroecology within the Czech Republic, especially after 1989 in connection with the development of the organic farming sector, is linked to initiatives and projects supporting changes in agricultural practice and education that originated and originate thanks to ministries, research organizations, and farmers themselves. The term agroecology can be used in multiple ways: as a science, as a movement, and as a practice. Broadly stated, it is the study of the role of agriculture in the world. Agroecology provides an interdisciplinary framework to study the activity of agriculture. 
Agriculture does not exist as an isolated entity, but rather as part of an ecology of contexts. Agroecology in Slovakia is understood only in the context of ecology and environmentalism, and its full nature has not yet been recognized. Thus, agroecology is the study of ecological processes that operate in agricultural production systems with an emphasis on the application of ecological principles to agricultural systems and practices.

Table 1. Agroecology in selected professional literature of the Czech Republic and Slovakia (until 1999).

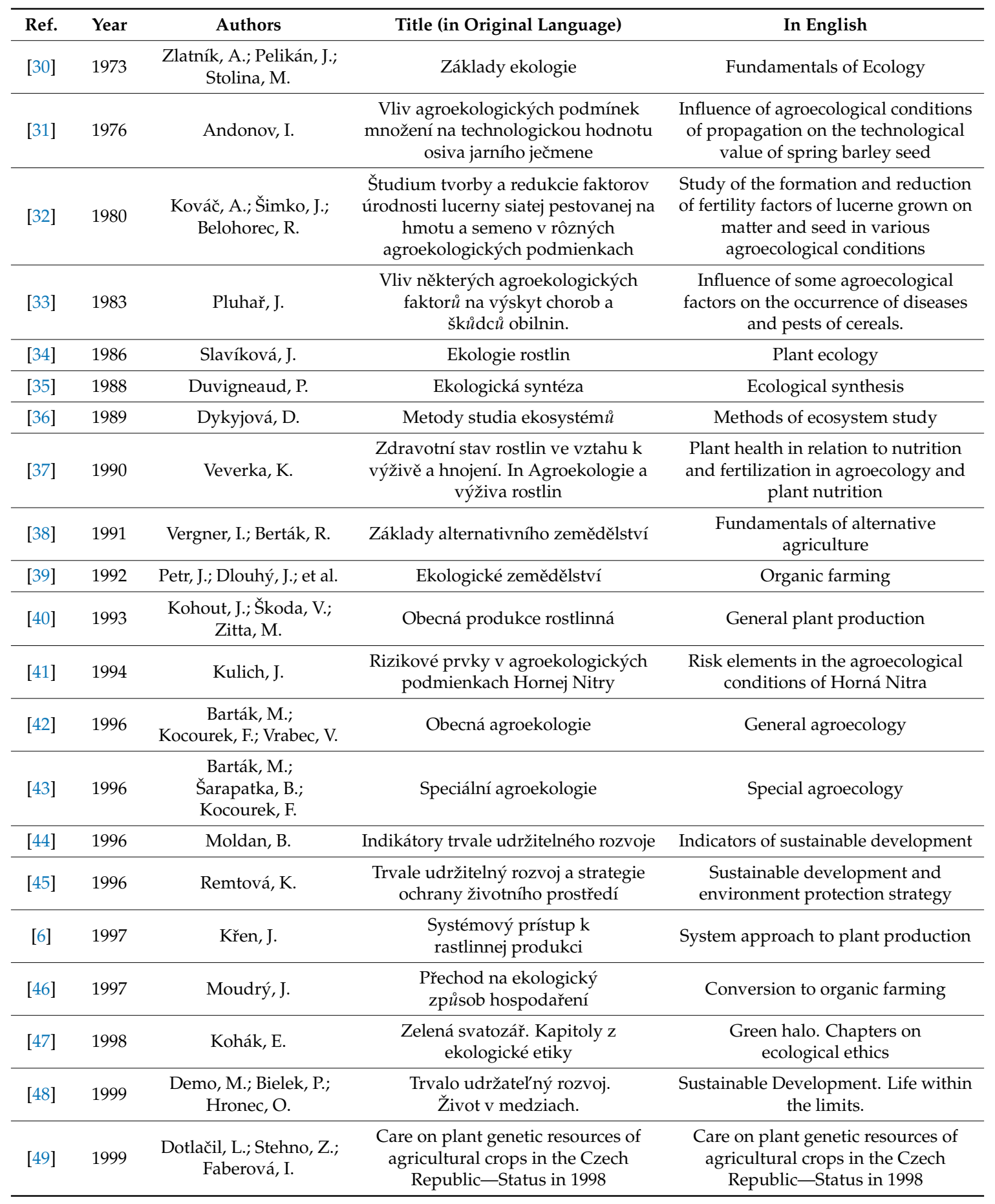

These studies support the science, practice, and movement to eliminate the underestimation of agroecology via national and international projects. 


\subsection{Agroecology in Hungary}

Agroecology is still in its infancy in Hungary. There are initiatives and projects promoting changes in agricultural practice and education, but these changes are very slow. Agricultural actors and stakeholders know in theory what would be good practice, but economic interests are against it. The economic viability of agroecological practice and its long-term effects should be better highlighted and supported by the government.

The concept of agroecology is becoming more and more well known in Hungary. Research, educational projects, international collaborations, and scientific conferences deal with the subject. There are associations and companies that are providing agroecology-related services. One good example is the National Society of Conservationists (Magyar Természetvédők Szövetsége, Üllői út 91/b, Hungary) [50] that was established in 1989. Their overall objective is to protect nature as a whole and promote sustainable development. They have 113 member associations, with almost 33,000 members across Hungary. A large number of the member groups are small, local organizations whose main activities include environmental education, awareness raising, participation in uncovering and solving local environmental problems, environmental advisory work, and nature conservation tasks. Among the society's educational publications, there is a specific issue related to agroecology (https:/ / $\mathrm{mtvsz} . \mathrm{hu}$ / kiadvanyok) that summarizes the concept of agroecology for a wider audience (not only for scientists). Another good example is the Agrofutura project [51], which has been dealing with agroecological issues for a long time, and has proven well-established technologies. The Agrofutura was founded in 2013 as an agricultural advisory, service, and manufacturing company. Agrofutura works with young scientists, mechanical engineers, and practicing farmers. They use technologies, which are based solely on biological farming. They work in balance with the humans-animals-plants-nature environment. They provide programs and services on subjects such as "Animal Welfare" and "Soil Humus Management". Both are based on teaming with the microbes. An important part of their activity is the education of farmers and families in order to support their real independence, self-care, and freedom. Hungary has recently been actively involved in important agroecological events. Last year (2016), the Regional Symposium on Agroecology for Sustainable Agriculture and Food Systems in Europe and Central Asia [52] was held in Budapest, which was organized by the FAO (World Food and Agriculture Organization, Rome, Italy). During this event, the Hungarian Minister for Agriculture confirmed that: "Agroecology is key in ensuring sustainable agriculture, [the] protection of biodiversity, sustainable natural resource management, and supporting rural development". The main goal of the symposium was to bring together the knowledge and experience already available among experts and to find solutions for the most urgent global challenges. FAO is an advocate and supporter of international cooperation. The symposium was also aimed at identifying government initiatives and starting to identify key entry points for agroecology in national policies and common European policies. Organic farming is still considered to be the best practice of agroecological farming. In Hungary, the appearance and spread of organic farming began in the eighties. At that time, it started as a movement in the form of networks. In 1987, the Biokultúra Association was established, providing the official organizational model of operation. The association not only unites the players in the organic movement and represents the interests of the members, it also performs educational and consultation tasks while providing scientific representation for the agricultural sector. Science also has an important role in the appearance of agroecology in Hungary. Several scientific projects related to agroecology were initiated, while educational research aimed at mapping out possible changes in relation to teaching methodologies of agroecology. 
In general, agroecology—as a discipline-studies agriculture from an ecological perspective that addresses the stability and optimization of the agricultural system as a whole. Agroecological farming is based on the well-established knowledge of traditional farming, which can possibly lag behind monoculture-based farming, but its sustainability is far more productive and energy-efficient [53]. Agroecology is a way of understanding the relationship between agroecosystems and the environment discipline [54]. In Hungary, agroecology—as a practice—encourages farmers to become part of the ecological system to strengthen processes that are inherent in nature and incorporate them into production (e.g., crop rotation, composting, soil cover, increasing biodiversity, alternative energy use, etc.). These elements are not included exclusively in the rules of organic farming; they also became a part of the direct payment (e.g., greening) in the case of conventional farming. Agroecology is also known in other countries as a movement, which does not present a significant polarity in Hungary. Meanwhile, in the bottom-up initiative, everyone agrees that agroecology can be the basis for food self-sufficiency; this may also affect public policy. The agroecology movement's participants (farmers, animal breeders, rural communities, consumers, NGOs, trade unions, local food movements, teachers, etc.) have concrete action ideas, but they vary and are not yet uniform. The movement of La Via Campesina is not very well known in Hungary, it forms part of the 'history' of the development of agroecology, but is not relevant within Hungarian circumstances.

Certain projects and initiatives have an important role in the current zeitgeist related to agroecology in Hungary. One of the most significant projects started in 2002 within the framework of the Hungarian National Research and Development Program. The consortium of the project, "AGRO-ECOLOGY" [55] (Environmental relationships of agro-ecosystems and the possibilities of their control), has undertaken the elaboration of an up-to-date agroecology synthesis. The soil science, water regime, agrometeorological, crop production, plant protection, biodiversity, and regional research studies outlined in the project included: the assessment of the elements of agroecosystems, the determination and analysis of the relationships and interrelationships with their functioning mechanisms; the description, characterization, and quantification of the environmental effects of different agroecosystems; the analysis of the effect of environment elements on different agroecosystems; the evaluation of the mass and energy transport processes in agroecosystems, and the soil-water-near surface atmosphere-plant system; the assessment of the factors affecting, determining, influencing or modifying their mechanisms and determining the possibilities of their control; and the elaboration of the basis of an up-to-date agroecological information system operating through interactive thematic expert systems. In 2003, the Hungarian Government and the Hungarian Academy of Sciences launched a joint research project entitled "Global climate change, its impacts in Hungary and responses" (VAHAVA project) [56]. The acronym comes from the abbreviation of the Hungarian key words "Change-Impact-Response" (VÁltozás-HAtások-VÁlaszadás). Since the National Environmental Program of Hungary was already dealing with the national tasks of controlling the emissions of greenhouse gases, consequently, the VAHAVA project focused primarily on the problems of vulnerability and adaptation in relation to the anticipated impacts of the climate change. The VAHAVA project [56] formulated two strategic objectives: (1) to get the Hungarian people and economy prepared to face the occurrence of potentially increased extreme weather, such as hydrometeorological events, and to bear warmer and drier time periods with their expectable impacts; and (2) to develop the organizational, technical, infrastructural, and financial conditions that would be needed for the timely response of their society to these harmful impacts. Both scientific research and projects focusing on new educational approaches were initiated after 2000. Szent István University was a partner of ISARA Lyon in the elaboration of their Agroecology MSc course; the University of Debrecen initiated its PhD program in 1993 with the name Crop Production, Agroecology. Why is education necessary for a better understanding of agroecology? Dover [57] defines and describes an ecological approach to agriculture that differs from the industrial approach that has dominated agricultural research and development for decades. Francis et al. [58] also emphasizes that much of the education in agriculture has moved from practical, hands-on field activities and internships to focus on 
theory in formal learning settings (mainly in classrooms). This is also true for Hungary. The growing need for productive and sustainable agriculture calls for a new view of agricultural development that builds upon the risk reduction and resource conservation aspects of traditional farming, and draws on the advances of modern biology and technology. In the suggested strategy of Dover [57], in order to attain sustainable agriculture, the importance of the research and education must be highlighted. In order for the development of ecological agriculture to grow roots, scientists need to train a whole new generation. Therefore, multidisciplinary comprehensive ecological-agricultural training is needed in agricultural universities that will develop a new generation of agroecologists who are capable of dealing with whole systems and provide agroecological knowledge for future policy makers $[59,60]$. On this basis, the SAGITER project (2013-2016 Project title: Agroecological Knowledge and Ingenuity of Terroirs) [61] focused on progress toward a sustainable agriculture education that can be achieved by combining both scientific and non-specialized knowledge. The project aim was to rebalance the asymmetrical vision of the world in which the scientific knowledge is regarded as rational and therefore "right", and the popular knowledge as irrational and therefore "wrong". Scientific approaches need to be combined with vernacular knowledge. The question is how the transmission of layman knowledge can operate in a corpus designed for science, and which methodologies need to be adapted in order to allow transmission to the concerned audience. It is also a question how the people who use the agroecological knowledge were able to acquire it, and how we can transfer everyday knowledge through training. In the SAGITER project [61], Szent István University from Hungary participated in the promoting/upgrading process of the agroecological knowledge, and the ingenious systems that are implemented from time to time on the territories. Of course, one single project could not result in a complete change in the knowledge transfer method applied at universities in Hungary, but practical method collection, which was elaborated during the three-year duration of the project, and related to knowledge transfer designed for educators, can surely support them during teaching. Methodology collection and can also reinforce the better understanding of the complexity of sustainable agriculture by providing a better view of the whole picture (even for the teachers!). The primary expected outcome of the project was still the awareness of the importance of the knowledge that cannot be acquired by university textbooks or the educational foundation of future responsible actions.

\subsection{Agroecology in Bulgaria}

In Bulgaria, there is some misunderstanding about the term agroecology, even among scientists and university teachers. Many of them equate the terms agroecology with organic farming. The increasing intensification of agriculture requires a deeper study of its impact on the environment. The results of these studies can serve as a basis for improving and expanding agroecological measures applied in agriculture. The first steps in the field of agroecology in Bulgaria were made in the 1990s. In 1987, the Agroecological Center was established as a structural unit of the Agricultural University-Plovdiv. It was founded with the aim of coordinating the efforts of researchers, students, farmers, and consumers to carry out research and provide education for the development of organic agriculture in Bulgaria. The priorities of the Agroecological Center are education and scientific research in the field of organic farming and agroecology [62,63]. Agroecological policy in the field of environmental protection is one of the most established mechanisms of the policy within the framework of the Common Agricultural Policy (CAP) for both the European Union (EU) and Bulgaria. In the beginning (after 1987), it was mainly aimed at mitigating the environmental impact of the intensification of agriculture and understanding the positive effects of extensive agriculture. Since 2000, many agroecological programs have been designed and implemented in Bulgarian agriculture through the seven-year rural development programs (RDPs). In 1993, the first scientific-practical conference, the "Ecological Problems of Agriculture" (AGROECO'93), was organized by the Agricultural University in Plovdiv [64] and the Union of Scientists in Bulgaria. Since then, such a conference has been held every second year. These conferences cover the ecological aspects of agricultural production. Crop production, soil and waters, plant protection, and animal production are the major topics for the focus 
points of the conference. The articles presented at the conference have been published in the "Scientific works", which is an annual agricultural book by the University of Plovdiv [64].

The Ministry of Agriculture, Food, and Forestry department's "Rural Development" and "Crop Production and Organic Production" programs, [65], the National Agricultural Advisory Service [66], the State Fund's "Agriculture" program [67], and the Ministry of Environment and Water [68] administer the agroecological policy. The State Fund "Agriculture" program provides financial support for these state aids under the supervision of the Common Agricultural Policy (CAP) and the Rural Development Program. The national agricultural advisory service provides free advice, information, training, and other services in the field of agriculture and the implementation for agroecological measures. Direct payments of European agroecological programs were started in Bulgaria by the SAPARD pre-accession program in 2000, and were continued in the following program periods 2007-2013 and 2014-2020 by green payments [69,70]. According to the 2014-2020 Bulgarian RDPs, two measures (M) cover agroecology: M10 (Agroecology and climate) and M11 (Organic Farming). Both measures relate to European programs supporting agroecology in Bulgaria that are targeted to: organic farming; the integrated production of agricultural products; expanding farming systems by reducing fertilizers and pesticides application, rotating crops, and taking actions to prevent or reduce soil erosion; the maintenance of genetic resources (local breeds threatened with extinction, plants threatened by genetic erosion); theconservation of biodiversity; actions to improve the landscape, including but not limited to the conservation of the historical characteristics of agricultural land (maintenance of traditional orchards and mountain livestock farming); and water, such as creating buffer strips, headlands, and wetland management. Many informal associations, foundations, and NGOs support agroecology and develop projects connected with different aspects of agroecology nowadays. The first and leading foundation in the field of organic agriculture is Bioselena [71], which was established in 1996 by the Research Institute of Organic Agriculture FiBL, Switzerland. The main task of Bioselena is to develop and support sustainable and organic agriculture, biodiversity preservation, and environment protection. One of the main goals of the Bulgarian Biodiversity Foundation (BBF, Sofia, Bulgaria) [72] is integrating biodiversity into key economic sectors through the implementation of European and world practice. The foundation is active in preserving natural resources, changing people's attitudes towards protected areas and protected species, increasing recognition of the subsequent opportunities and benefits of protected areas, and working for their long-term protection. The Bulgarian Society for the Protection of Birds (BSPB) [73], which is based on years of research and analysis on globally endangered bird species such as the imperial eagle, Egyptian vulture, and migratory geese that winter in Bulgaria, makes proposals to state organizations for accepting agri-environmental activities and measures to protect endangered bird species. Most of the members of the Association of Agroecological Farm Producers (AAFP) [74] are farmers who apply agroecological measures of RDP. The main goals of the AAFP are to support and inform agroecological farmers about compliance with the requirements for the implementation of agroecological activities; increase farmers' knowledge of the environmental benefits of agroecology; and support state structures through participation of the association in working groups, committees, expert councils, etc., in the preparation of legislative initiatives related to agroecological activities. The association "Ekofarm", together with the Agricultural University popularizes organic farming and agroecology through round tables and seminars in different towns and regions of the country [75]. The NGO organizations develop and work on different projects connected with agroecology and the environment. Some of the projects are in cooperation with other international institutions. For example, the "Assessment and mapping of the state of grass ecosystems and their services in Bulgaria" project was developed by the BSPB in cooperation with the Norwegian directorate for nature management (DN). The "Conservation of the Saker Falcon in northeastern Bulgaria, Hungary, Romania and Slovakia" project was developed in cooperation with 14 organizations from the countries that are included in the project. The main beneficiaries of agroecological payments are farmers. There are qualification requirements in order for them to receive these payments. Farmers should have finished a vocational secondary school 
or university with agricultural qualifications. Another possibility for the farmers is to complete the educational (training) course in agroecology and get certification, which allows them to apply for financing from state programs and varied programs requiring these qualifications (agroecology). The Agricultural University in Plovdiv is the first state university in Bulgaria where different courses connected with the topic of agroecology have been organized. The faculty of Plant Protection and Agroecology has two main professional fields: Plant protection and Ecology, and Environmental Protection. Courses in Agroecology and Agroecology and the management of agroecosystems are part of the Bachelor and Master degree programs. The Faculty of Agronomy at the University of Forestry in Sofia teaches a course in Agroecology. Other institutions offering courses in Agroecology are centers for continued education, which were established as supporting units at universities (e.g., Agricultural University, Plovdiv; University of Ruse, etc.) or centers for professional education. For example, the Centre for Professional Training or the Foundation of Organic Agriculture (FOA) "Bioselena" [71] is licensed for training the professional "Farmer". It offers training in Agroecology and Organic Farming. Other similar centers for vocational training include "Harmony", "Zenit", etc. Research in the field of agroecology is conducted at the Agricultural University of Plovdiv, the University of Forestry, and at the research institute of the Agricultural Academy and Institute of Soil Science, "Nikola Pushkarov".

As a drawback, it can be noted that the number of larger projects targeting agroecology in the country are still small. State institutions, universities, and scientific organizations must initiate deeper projects related to the influence of the environmental issues in agriculture. One of the recent agroecological projects that was developed with the participation of Agricultural University is "Sustaining agricultural change through ecological engineering" (STACCATO, 2014-2018), financed by European program Biodiversa [76]. The project plans to quantify the dependence of ecosystem functions and the services they generate on environmental pressures in representative agriculturally dominated landscapes within Europe. The focus is on local as well as regional land use intensity and biodiversity, and the potential impacts of future climate and land-use change. Ecosystem functions and services such as nutrient cycling and crop production, biocontrol, and pollination and identity with cultural landscapes will be studied. Studies are planned in representative regions across Europe on landscapes that are shaped by annual crops and semi-natural grasslands.

\subsection{Agroecology in Romania}

In Romania, the history of agroecology is relatively short and started in 1977-1978. As a science, one teacher team from the Agronomy Institute of Cluj-Napoca laid the foundation of its agroecology through the publication of many courses, papers, and books. Later on, the theoretical spirit of agroecology was disseminated in Timis,oara, Bucharest, and other Romanian agricultural university centers. These pioneers of agroecology defined agroecology as a branch or domain of general ecology that is dealing with the multidisciplinary study of influences exercised by environmental factors to crops and domestic animals (agricultural autecology), as well as the ecological research of structure and dynamics of agroecosystems (agricultural synecology). They also established the object and laws of agroecology. Therefore, as a scientific discipline, agroecology was conveyed by individuals with a range of expertise in ecology or biology, especially in the physiology of plants and agronomy, as well as in circumstances related to local and global problems of industrial agriculture because of neglectful of fundamental laws of living. The agroecology was extent then, in the 1984-2000s, and was more or less concomitant as a practice by delimitation and characterization of the homogeneous ecological territories (TEO), which were the basic units of the Romanian agroecosystems, and as movement by the foundation of four representative NGOs: the Organic Farmers Association of Romania (BIOTERRA), Calea Victoriei 21-23, Bucuresti [77], the Romanian Association for Sustainable Agriculture (ARAD) [78], the Agroecology Association (Agroecologia) and the National Federation of Ecological Agriculture (FNAE), str Manastur 3-5, Cluj-Napoca [79]. Another important step for agroecology development in Romania was the defining of sustainability as a feature of the (agro)ecosystems, and the development of its indicators. These included (bio)diversity, vulnerability, 
and resilience, as well as indicators of other (agro)ecosystem features such as: the complexity and unity of its integrality; and the productivity, efficiency, stability and equity of its functionality. The Romanian agroecosystems were delimitated and characterized in the framework of the national research program "Zonal Intensive agroecosystems" between 1985-1989. Also, the foundation of the first NGOs that focused on agricultural ecology took place between 1987-2000 following the development of the IFOAM and elaboration of the first international and national legal frameworks for agricultural products and foodstuffs obtained organically from European regulation 2092/91 and O.U.G. 34/2000, respectively.

Today, the object of agroecology is more diversified, from initial activities regarding crop production and plant protection, agricultural practices, and movement to the environmental, social, ethical, and development aspects of all food systems. In this context, the stakeholders in agroecology are diverse and active in education (Agricultural universities), agriculture production (organic farms), research and innovation (Research, Innovation, and Technical Assistance Center for Ecological Agriculture of NARDI Fundulea) [80], the promotion of small-scale family and traditional farming (Agroecologia Association and Mihai Eminescu Trust), 10 Cojocarilor Street Sighișoara [81], civil society, including peasants (Eco-Ruralis, Cluj-Napoca, Romania) [82], etc. The shareholders are a smaller agroecology group that is active in research, innovation, education, and rural civil society.

In Romania, there are three categories of players who convey agroecology. (1) First, there are professors and scientists, who are supporters of agroecology and promoters of small-scale family farming, etc., who use terms such as agroecology, agricultural ecology, and agroecosystem frequently and with full knowledge. (2) Second, there are professors who reject, without further explanation, the terms of agroecology and agroecosystem, and use only the terms agricultural ecology, or agricultural (artificial) ecosystems. (3) Third, there are some of the authors and lecturers from the "Ecology and Environmental Protection" discipline in agricultural universities and faculties who dedicate only a few hours (one to two) for agricultural ecology and agricultural ecosystems. Be aware of the opposition that is evident within applied agroecology because of two parallel terms: "eco", when discussing agriculture systems, and "bio" when referring to products; this is despite the official term in Romania, which is protected and assigned by the EU, and is "Agricultură ecologică". In this case, it is normal that the terms agroecology, agroecosystem, and ecological agriculture cause confusion among scientists and the public. In regards to vision, agroecology is the basic science of sustainable agroecosystems for the unilateral treatment of all types of farming systems. This vision is realistic and based on recent communications from the EU's "Future of Food and Agriculture" report, which outlines both the main and new priorities of the future EU agricultural policy. These are: (1) intensifying protection of the environment (soil, water, air, and biodiversity) as well as the climate; (2) increasing the focus on knowledge and innovation (smart agriculture); and (3) promoting a bioeconomy. In this context, some measures and clearing up the message about agroecology is necessary:

- The definition of agroecology has to be completed with environmental, social, and ethical aspects of the agroecosystems, which are now missing;

- The laws of agroecology have to be reviewed and disseminated to agroecosystems and rural development;

- Firmly establishing agroecosystem features and their indicators is a crucial aspect of investigation for evaluating and anticipating solutions for farm design and management, as well as land use policies;

- Developing basic standards of agroecology is the main tool for the implementation of agroecology in practice.

In Romania, there are numerous initiatives that support the development of agroecology (see Table 2), and also older publications about agroecology topics (see Table 3). 
Table 2. Initiatives supporting the development of agroecology in Romania.

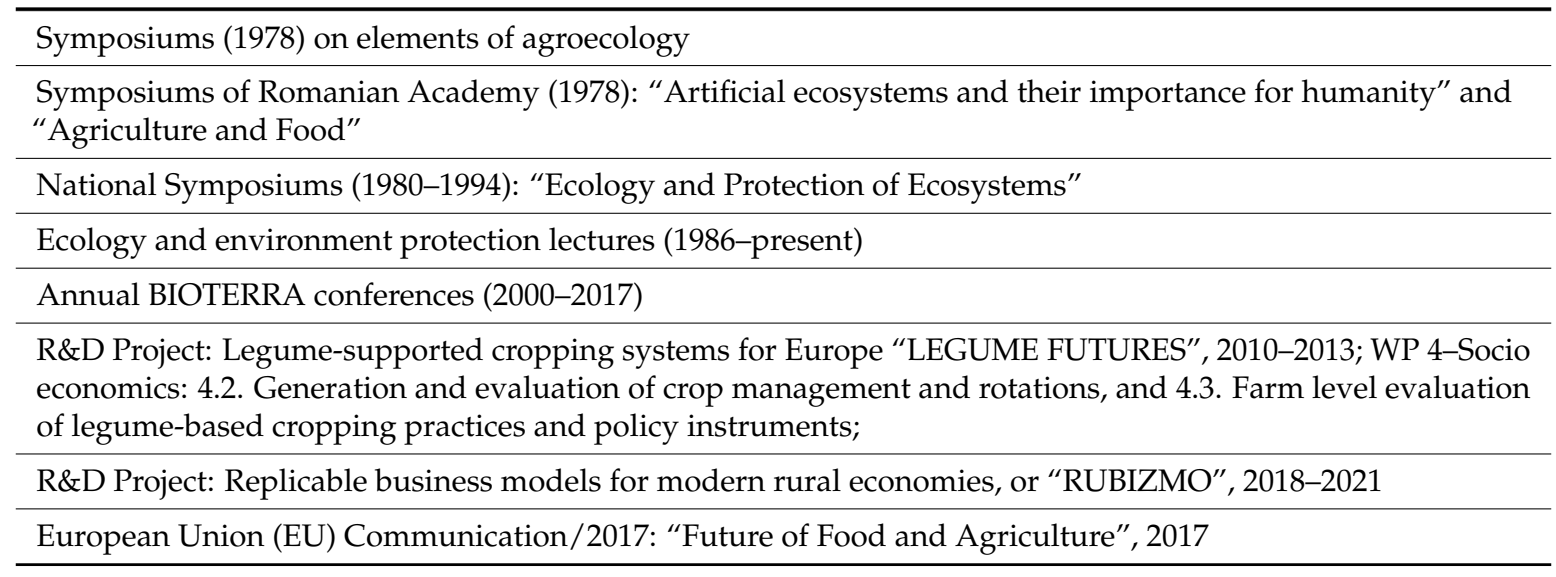

Table 3. Agroecology in selected professional literature of Romania (until 1999).

\begin{tabular}{ccccc}
\hline Ref. & Year & Authors & Title (in Original Language) & In English \\
\hline$[83]$ & 1977 & Puia, I.; Soran, V. & Umanitate și agroecosisteme & Humanity and agroecosystems \\
\hline [84] & 1978 & $\begin{array}{c}\text { Puia, I.; Soran, V.; } \\
\text { Klemm, H.; } \\
\text { Popescu, V.; Erdelyi St., } \\
\text { Tatau, V. }\end{array}$ & Elemente de agroecologie & Elements of agroecology \\
\hline- & $1980-1984$ & Ionescu, A.; et al. & - & $\begin{array}{c}\text { Proceedings of symposiums } \\
\text { “Ecology and Ecosystems } \\
\text { protection" }\end{array}$ \\
\hline$[85]$ & 1984 & Puia, I.; Soran, V. & $\begin{array}{c}\text { Agroecologie: ecosistem si } \\
\text { agroecosistem }\end{array}$ & $\begin{array}{c}\text { Agroecology: ecosystem and } \\
\text { agroecosystem }\end{array}$ \\
\hline$[86]$ & 1986 & Coste, I. & Ecologie Agricola & Course of agricultural ecology \\
\hline$[87]$ & 1998 & $\begin{array}{c}\text { Puia, I.; Soran, V.; } \\
\text { Rotar, I. }\end{array}$ & $\begin{array}{c}\text { Agroecologie, Ecologism, } \\
\text { Ecologizare }\end{array}$ & $\begin{array}{c}\text { Agroecology, Ecologism, } \\
\text { Ecologization }\end{array}$ \\
\hline [88] & 1999 & Toncea, I.; Alecu, I.N. & Ingineria sistemelor agricole & Engineering of agricultural systems \\
\hline
\end{tabular}

\subsection{Agroecology in Poland}

The beginning of agroecology in Poland is closely linked to the development of organic farming. First, organic and biodynamic farms and farmer associations were established at the end of the 1980s; these formed the base for the development of agroecology in the successive years. Currently in Poland, the following practices can be linked with agroecology: organic and biodynamic farming; agri-environmental schemes; and permaculture, as well as agroforestry.

Organic and biodynamic farmers constitute the main pillar of players whose activity can be linked to agroecology. In 2016, there were 22,435 organic farmers in Poland managing about 537,000 ha of agricultural land. This constituted about $3.7 \%$ of the total Polish agricultural area (IJHARS 2017) [89]. There are no precise statistics on biodynamic farms in Poland, but their number is rather small. Farmers implementing biodiversity conservation-oriented packages of agri-environment schemes (AES) belong to another important group of players linked to that particular form of agroecology. In 2015, there were about 650,000 ha of grasslands under this type of AES, this was about $20 \%$ of all of the permanent grasslands in Poland. Permaculture is another example of practical agroecology. There were about 40 different permaculture initiatives across Poland, representing both the practice (farms) and the movements (Permakultura 2017) [90]. There are no statistics on agroforestry in Poland; however, there are already some examples of farmers implementing this type of agroecological practice. 
The organic movement is quite strong in Poland. There are numerous NGOs that are strictly connected with organic agriculture in Poland. The following table (Table 4) lists them in chronological order.

Table 4. Non-governmental organizations (NGOs) strictly connected with organic agriculture in Poland.

Association of Food Producers with Ecological Methods EKOLAND (created in 1989). The oldest Polish organization dealing with organic farming.

Ecological and Cultural Association "Ziarno" (created in the late 1980s). Inspired by the biodynamic farmer Julian Osetek. Education and promotion are the main goals of this association.

Polish Society of Organic Farmers (PTRE), ul. Jacka Kaczmarskiego 27, Warszawa, is a Polish society or collective of farm producers possessing certified organic farms. Created in the early 1990s.

Union of Associations of Subcarpathian Chamber of Organic Farming is an organization created in 2005 that brings together five associations of organic farmers, producers, and processors from the region.

Association "EkoLubelszczyzna" was created in 2006, in the interests of its members to implement the strategy for the economic cluster "Organic Food Valley".

Lesser Poland Association of Organic Farmers Nature was founded in 2007 to help organic farmers in the province with the promotion and sale of organic foods on the market.

The Trade Union of Organic Farmers of St. Francis from Assisi is a nationwide organization bringing together farmers who run farms organically. Created in 2007.

The Association Forum of Organic Agriculture named by M. Górny and created in 2009. The goal is to distribute organic farming practices among agricultural producers and processors and promote organic products. Another important aim is to inspire and encourage science that supports the development of organic farming in Poland.

Kuyavian-Pomeranian Association of Organic Producers (EKOŁAN). Promotion of organic farming and its products is the main goal. Created in 2012.

National Association of Processors and Producers of Organic Products 'Polish Ecology'. The mission of the association is to inform consumers and increase trade possibilities. Created in 2015.

Polish Chamber of Organic Food is a group of traders within the organic food industry that brings together its most important representatives. Their mission is to promote healthy lifestyles by educating Polish society about what is organic food, which relates to the process of its production, and how is it different from conventional food. Particular emphasis is placed on the label of certified food. Created in 2017

Through analyzing the list above, one can conclude that at the start, there were only three associations that were historically connected with the beginning of the development of organic farming in Poland. The following eight associations were created much later, from 2005 through 2017, in parallel to the dynamic development of organic farming and processing. The main goal of all of these organizations is to bring together the organic producers and other stakeholders in order to increase opportunities for promotion and product trade. Another important aim is to increase the awareness of the consumers about the high properties of organic food. Here, we refer specifically to the Ziarno and Forum of Organic Agriculture named M. Górny, which is the most scientific organization amongst those listed. Many researchers who have conducted studies related to organic production belong to this association. The two last organizations have a strong economic aim: Polish Ecology and the Polish Chamber of Organic Food. There are at least four non-governmental organizations focused on permaculture. These are mainly foundations directed by educational activities for different players. As far as agroforestry is concerned, in 2015, a Polish Agroforestry Association was registered, and started activities that aimed to increase social awareness on the value of trees in an agricultural landscape and promote the practice of agroforestry across Poland (Agroforestry 2017) [91].

In recent years, interest in agroecology has been observed in the higher education sector. For example, the Agricultural University of Kraków's Department of Agroecology has been working in this area for many years. Furthermore, a master's degree specialization in Agroecology was developed within the Faculty of Biotechnology and Horticulture at the University of Rzeszów. Moreover, 
at Rzeszów University of Technology, the subject Agroecology was introduced within studies on environmental protection. A special e-learning course for students on Agroecology was realized in the Warsaw University of Life Sciences between 2009-2013 within a project financed from EU structural funds. Additionally, last year, Opole University offered a postgraduate study in Agroecology specifically for those running or planning to run an organic and/or agritourism farm. A very important institution strongly involved in agroecology research is the Institute for Agricultural and Forest Environment (IAFE) at the Polish Academy of Sciences in Poznań (former name: Research Centre for Agricultural and Forest Environment). The institute, among others, has been engaged in research on farmland biodiversity patterns and its dependency on habitat and landscape structure. Several research institutions and universities in Poland have been involved in organic farming research in recent years. Although many detailed topics have been the subject of this research, their link with agroecology is rather poor, and is often related to organic farming education.

Several bottom-up, mainly educational initiatives or movements supporting the idea of agroecology have been initiated in Poland over the last 30 years. This sector of practice is also strong, as there are still many organic and AES farmers all over Poland. Organic farming research has been quite comprehensive covering different areas of knowledge; however, in most of the research, there is a lack of a clear link to agroecology.

Some examples of initiatives that are considered as illustrating the aforementioned situation and dynamics follow. They can be: existing or transitioning systems, events, training courses, research agendas, websites, etc. The Ecological and Cultural Association ZIARNO in Grzybów in the central part of Poland is a very good example of a movement linking organic farming, permaculture, and innovative education under the umbrella of agroecology. In this region, beginning in 2014, an Ecological Folk High School that was based on Grundtvig folk universities for the innovative education of adults was successfully implemented. The association is also very active in supporting sustainable local development [92]. Another interesting example of practical agroecology linking practice, movement, and science in one place is the biodynamic farm in Juchowo in the northwestern part of Poland. This farm breeds milking cows and covers almost 2000 ha of land for arable crops, vegetables, and permanent grasslands. There are different social activities in the farm, including education, which is mainly for children (green schools), research (experiments on comparing different soil tillage systems), and social therapy, especially for disabled people [93].

\section{Comparison of Agroecology in Selected Countries of Eastern Europe}

The main impulse for the development of agroecology in the Eastern European countries under review is the negative impact of intensive large-scale agriculture on the environment and the depletion of natural resources; however, the demand for quality foods is also important. Conventional agriculture does not always secure the ability of the soil or the entire agroecosystem to maintain the production levels over a long period. The growing population prompts the need for productive as well as sustainable agriculture. While maintaining a sufficiently strong production function, such agriculture should be in harmony with nature, preserve resources, and utilize the positive impacts of environmentally friendly measures.

In agricultural practice, the support of agroecological principles has been gaining ground more slowly. Familiarization with various problems and the negative impacts of intensive conventional agriculture on the production and its quality and on the environment increase the interest of farmers in scientific information and their willingness to apply the outputs of agroecological research. Motivation is also stepped up by pressure from the general and professional public, the media, and end customers. Openness to agroecological research on the part of politicians and farmers in Central and Eastern Europe is also due to the support of sustainable farming within the scope of the common agricultural policy.

In the Eastern European countries under review, agroecology is addressed especially by research and educational institutions (Figure 1). A strong role is also played by movements and 
non-governmental organizations (NGO), which are regarded, in overall assessment, as the second strongest actors participating in the development of agroecology. The influence of the state, or rather government authorities, is lower, and the lowest influence is exerted by farmers themselves. Only in Bulgaria and Hungary is the role of government authorities higher, and comparable with the influence of movements and NGOs.

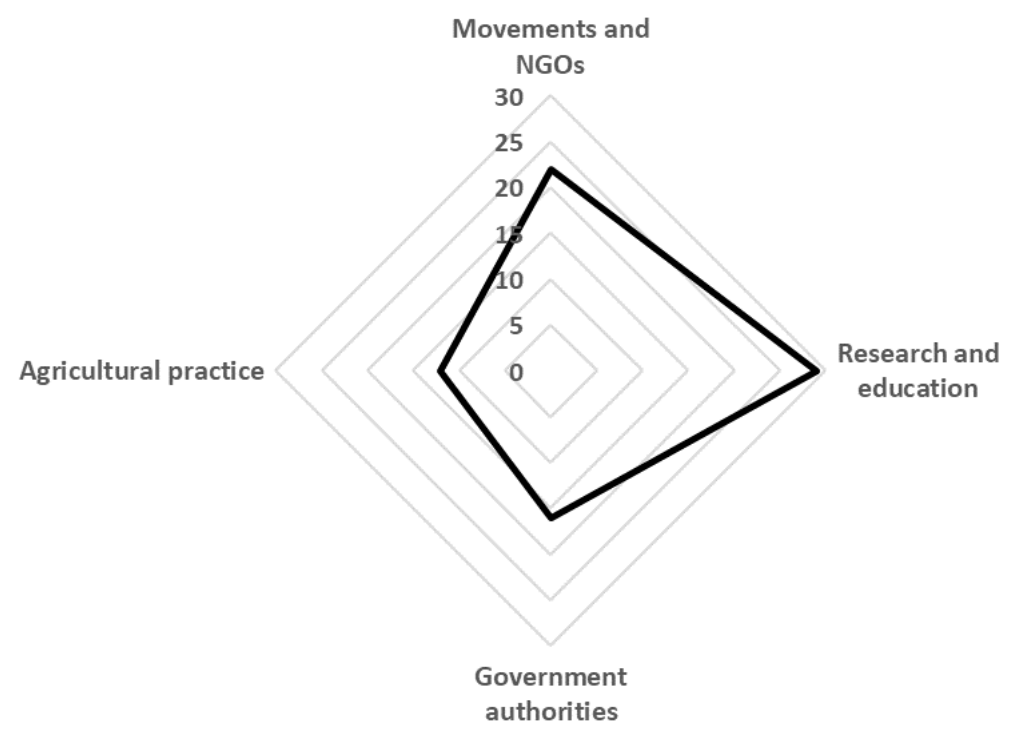

Figure 1. Influence of main actors on the development of agroecology.

The farmers themselves have not yet been perceiving agroecology as a separate discipline much. Certain aspects have been fulfilled in organic farming, but the overall demand for the development and support of agroecological measures that are bottom-up driven by the farmers themselves is very low. Therefore, the perception of agroecology by government authorities has also been rather low so far, and various elements of agroecology are addressed as part of the agenda related to the development of organic farming and environment protection. However, the influence of government authorities has been gradually growing, e.g., in Hungary where, in Budapest, in 2016, the Food and Agriculture Organization (FAO, Rome, Italy) organized the Regional Symposium on Agroecology for Sustainable Agriculture and Food Systems in Europe and Central Asia, at which the Hungarian Minister of Agriculture declared the need for a cooperative approach among government authorities and efforts to develop agroecology. The symposium also identified governmental initiatives and began to identify key inputs for agroecology in national policies and in common European policies. In Bulgaria, but also in the Czech Republic, Poland, and Romania, there have been growing efforts by government authorities to support agroecology in recent years, in particular by the application of European agroecological programs for the support of agroecological procedures. In Slovakia, the importance of agroecology for sustainable food production has not yet been sufficiently understood by governmental authorities, which results in poor support for targeted procedures. It is expected that, apart from further development in the fields of science, research, and education, the interest of NGOs in the field of agroecology will also grow in the future and, in consequence, direct agricultural practice will begin to play a more important role.

What has a significant effect on the development of agroecology is the sphere of research and education. In most of the Eastern European countries under review, there are study programs (fields) in Agroecology available at universities (Table 5). In the Czech Republic, the study field named Agroecology may be studied on all levels (Bachelor, Master, PhD); in Romania, these degrees are also available, but the study fields are called Ecology and Environment Protection and cover subjects such as Organic Farming and Ecology. Since 1993, the PhD degree may be obtained in Hungary (programs: Crop Production, Agroecology). The Bachelor study field called Agroecology also appears in Slovakia, 
where it is supposed to be accredited in 2018. A Master study program is available in most cases, but in a number of countries, Agroecology is also included in another study field with a different name, which is e.g., the case in Bulgaria, Poland, or Slovakia, where Agroecology is included as a separate subject in other study programm, or in Hungary, where there is no study field called Agroecology, although there are 54 Bachelors, 52 Masters, six undivided Master, and 16 VET (Vocational Education and Training) programs currently accredited in the country.

Table 5. Education and research in agroecology.

\begin{tabular}{|c|c|c|c|c|c|c|c|}
\hline & & BG & $\mathrm{CZ}$ & HU & PL & RO & SK \\
\hline \multirow{3}{*}{$\begin{array}{l}\text { Existing study programmes at } \\
\text { universities/colleges }\end{array}$} & Bc. & $\mathrm{No}$ & Yes & No & No & Yes & Yes * \\
\hline & MSc. & Yes & Yes & No & Yes & Yes & Yes \\
\hline & Ph.D. & No & Yes & Yes & No & Yes & No \\
\hline \multicolumn{2}{|c|}{$\begin{array}{c}\text { Number of universities/colleges offering a study } \\
\text { program in Agroecology }\end{array}$} & 2 & $3^{* * *}$ & 1 & 1 & $16^{* *}$ & 1 \\
\hline \multicolumn{2}{|c|}{$\begin{array}{l}\text { Are there any lower-tier schools offering a study } \\
\text { program in Agroecology? }\end{array}$} & Yes & No & No & No & No & No \\
\hline \multicolumn{2}{|c|}{$\begin{array}{l}\text { Are there any research institutions (or their separate } \\
\text { departments) directly addressing Agroecology? }\end{array}$} & No & No & No & No & No & Yes \\
\hline
\end{tabular}

* The study field will be accredited in 2018; ${ }^{* *}$ The study fields have different names but their contents are identical;

*** In one case the study field has a different name, but its content is identical.

At lower education levels, the Agroecology program is available only in Bulgaria, where it is taught in a majority of the secondary schools that feature agriculture (Table 5). In the other countries under review, the topic is included in other programs that are focused in particular on sustainable forms of agriculture, organic farming, environment, ecology, etc.

Except for Slovakia, where there is the Agroecology Research Institute in Michalovce, in none of the countries under review was there any research institution or its separate department directly focused on agroecology (Table 5). Agroecology or its parts are mostly included in other topics, e.g., at the Institute of Soil Biology of the Academy of Science of the Czech Republic (CZ), the Agricultural Academy in Sofia, the Agricultural University in Plovdiv, the University of Forestry in Sofia, Trakia University in Stara Zagora (BG), the Institute for Soil Sciences and Agricultural Chemistry and Centre for Agricultural Research in the Hungarian Academy of Sciences; the National Agricultural Research and Innovation Centre and the Agro-Environmental Research Institute (HU), and the National Research and Development Institute for Soil Science, Agrochemistry, and Environmental Protection (RO). In the past, in Poland, there was the Department of Agroecology at the Institute of Ecology of the Polish Academy of Science. In the Czech Republic, this sphere was addressed by the Institute of eco-agrotechnics, but those institutions do not exist anymore.

In practice, agroecology receives support in all of the countries under review, mostly from the programs connected with the European subsidy schemes, which address various topics falling under agroecology (Table 6). For example, in Poland or the Czech Republic, this concerns agro-environmental measures/programs, in particular. In Slovakia, the Ministry of Agriculture and Rural Development of the Slovak Republic also funds the Research Institute of Agroecology in Michalovce as part of the National Agricultural and Food Center.

Agroecology, or topics falling under this field, is supported in the field of research (Table 6) in the Czech Republic, Hungary, Poland, and Romania. In Bulgaria and Slovakia, the topic of agroecology may appear as part of calls of subsidy agencies, but there have not yet been any programs focused substantially on the support of agroecology or its parts. In the Czech Republic, agroecological topics are regularly announced e.g., in the program Earth under an agency of the Ministry of Agriculture; in Hungary, topics falling under agroecology form part of the Environmental Program of Hungary; in Romania, they are e.g., part of the Small Grants Program (SGP) of Global Environment Facility (GEF) 
(e.g., sub-program Smart Innovative Agroecology in Terms of Climate); and in Poland, there is support of organic farming as well as agri-environment schemes' (AES) scientific programm.

Table 6. Support of agroecology development.

\begin{tabular}{cccccccc}
\hline & BG & CZ & HU & PL & RO & SK \\
\hline $\begin{array}{c}\text { Are there any national programs to } \\
\text { support agroecology in practice? }\end{array}$ & Yes & Yes & Yes & Yes & Yes & Yes \\
\hline $\begin{array}{c}\text { Are there any national programs to } \\
\text { support research in agroecology? }\end{array}$ & No ${ }^{*}$ & Yes & Yes & Yes & Yes & No * \\
\hline $\begin{array}{c}\text { Apart from the Ministry of Agriculture, } \\
\text { do other ministries address agroecology? }\end{array}$ & Yes & Yes & Yes & Yes & Yes & Yes \\
\hline
\end{tabular}

* The topic of agroecology may appear in some calls of subsidy agencies.

In all of the countries under review, agroecology is addressed in particular under the responsibility of the Ministry of Agriculture, but some other ministries (Table 6), mostly the Ministry of the Environment (BG, CZ, PL, RO), are also involved everywhere. Agroecology is also marginally addressed in the Czech Republic by the Ministry of the Interior or by the Ministry of Education, Youth and Sports; in Slovakia by the Ministry of Education, Science, Research and Sports of the Slovak Republic; in Romania by the Ministry of Waters and Forests and by the Ministry of National Education; and in Hungary by the Ministry of the Interior and by the Prime Minister's Office.

Although the influence of movements and NGOs on the development of agroecology is regarded to be quite high in the countries under review, we cannot find any NGOs focused primarily on agroecology (Table 7). The two exceptions are: Hungary, where there is an NGO addressing agroecology as the main topic, namely Agrofutura, which has been dealing with these issues over a long period and, apart from the support of research, also educates farmers; and Romania (e.g., Solidarity and Hope Foundation Iasi's Center for Agroecology). However, agroecology or its parts are considerably addressed by movements and NGOs that are aimed particularly at the environment, ecology, or organic farming (Figure 2). The topics that the movements and NGOs regard as the most important are ecology (CZ, HU, RO, SK), the environment and human impacts on the environment, organic farming (BG), and the related food quality, or the aforementioned topics are in balance (PL), and agroecology is included in them rather than being a separate topic.

Table 7. Movements focused on agroecology and consultancy.

\begin{tabular}{|c|c|c|c|c|c|c|c|}
\hline & & BG & $\mathrm{CZ}$ & HU & PL & RO & SK \\
\hline Are there any NGOs fo & directly on agroecology? & No & No & Yes & No & Yes & No \\
\hline \multirow{4}{*}{$\begin{array}{l}\text { Are there consulting } \\
\text { organizations focused } \\
\text { directly on: }\end{array}$} & Agroecology & Yes & No & Yes & No & No & No \\
\hline & Ecological farming & Yes & Yes & Yes & Yes & Yes & Yes \\
\hline & Conventional farming & Yes & Yes & Yes & Yes & Yes & Yes \\
\hline & Ecology & Yes & Yes & Yes & Yes & Yes & Yes \\
\hline \multicolumn{2}{|c|}{ What is mostly addressed in consultancy? } & $\mathrm{CF}$ & E & $\mathrm{CF}$ & $\mathrm{CF}$ & E & CF \\
\hline
\end{tabular}

Considering that the involvement of farmers in agroecological issues has been rather low so far, agroecology is also only marginally covered in consultancy (Table 7). Consulting organizations specialized in agroecology operate in Bulgaria (Association of Agroecological Farm Producers-AAFP, Sofia, Bulgaria) and Hungary. In other countries, the aspects of agroecology are covered by consultancy mainly in the fields of ecology (environment) and organic farming, and to a lesser extent in the consultancy for conventional farming. 


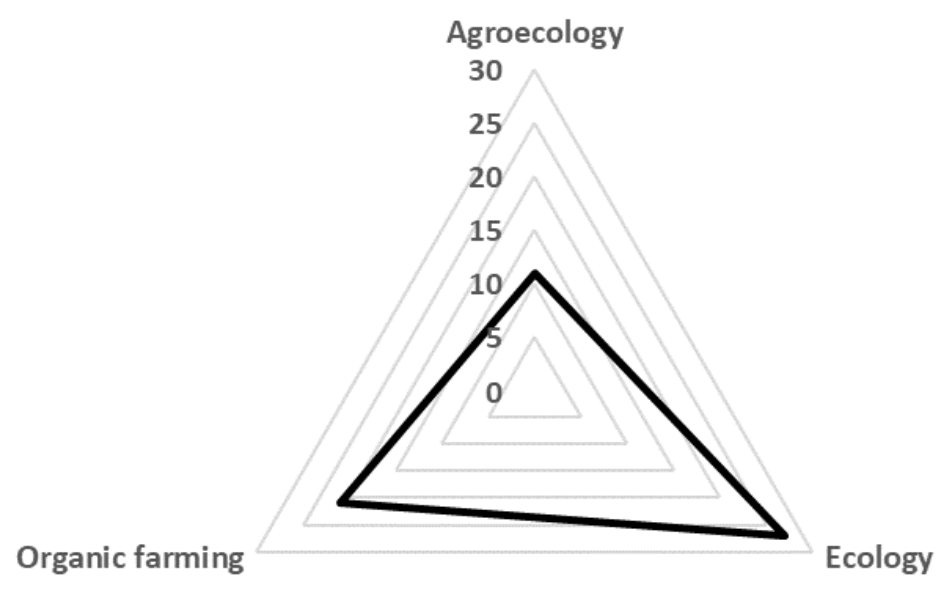

Figure 2. Focus of environmental movements and NGOs.

Consultancy as a whole is mostly aimed at conventional farming (BG, HU, PL, SK) or the environment and ecology (CZ, RO); ecological farming is covered less in consultancy (also because of its considerably lower extent).

The development of agroecology largely depends on the approach of farmers. In the countries under review, the agroecological principles are practically fulfilled rather unwittingly in organic farming, and the perception of agroecology as a separate field is low. In the Eastern European countries under review, agroecology often began to be mentioned and developed earlier than ecological farming, which began to appear more massively after the break-up of the Eastern Bloc and the change of the regime in individual countries at the end of the 1980s and beginning of the 1990s. Agroecology as a scientific field responds in particular to the environmental problems of agricultural practice and, from this point of view, it is closely linked to agriculture. However, at the same time, agricultural practice (including ecological one) makes insufficient use of the agroecological research outputs for its development, thus making this link one-sided to a certain degree.

This is also connected with a quite low perception of agroecology as a separate field by farmers (Table 8). In all of the countries under review, agroecology is a rather unclear concept for a majority of farms, and its elements are systematically developed only by a minority of farms (mostly ecologically managed ones). The impact of education is also visible here; e.g., in Slovakia, agroecology graduates have a considerably larger knowledge than most of farmers and also use such knowledge in practice. A lower knowledge of agroecological principles possessed by a majority of farmers is also evident from the perception of the introduced cross-compliance in the EU, which is understood by a majority of farmers rather as another of the series of regulations that have to be fulfilled in order to get subsidies. Only a small portion of farmers fully understands the environmental benefits and their positive impact on farming itself.

Table 8. Agroecology and agricultural practice.

\begin{tabular}{ccccccc}
\hline & BG & CZ & HU & PL & RO & SK \\
\hline $\begin{array}{c}\text { Do farmers perceive agroecology } \\
\text { separately from ecological farming? }\end{array}$ & 2 & 2 & 2 & 2 & 2 & 2 \\
\hline $\begin{array}{c}\text { Has the introduction of cross-compliance } \\
\text { in the EU raised the awareness and } \\
\text { interest of farmers in agroecology? }\end{array}$ & No & No & No & No & No & No \\
\hline
\end{tabular}

${ }^{*}$ Evaluation scale $1-5(1=$ almost none $2=$ minority $3=$ half 4 = majority $5=$ almost all $)$. 
Given certain similarities in the current state of agroecology in the Eastern European countries under review, the expected development of agroecology is also predicted to be quite similar. Agroecology will continue being developed as a scientific field linking production and environmental aspects of agriculture, and agroecological research has to be coordinated, institutionalized, and closely interconnected with education. The inclusion of agroecological topics in agricultural education on professional and university levels will enhance the agroecological knowledge of professionals and farmers, and it will also be important to educate the broader public. The support of agroecology by government institutions is an important factor and a tool to achieve sustainable farming. The form of support of ecological farming should be extended to the targeted support of agroecological procedures and conventional production as well. Assertion of agroecology in practice will be slower and conditioned by the understanding of its principles both by the government authorities and the farmers.

\section{Conclusions}

The development of agroecology is closely linked to the development of organic farming in Eastern European countries under review. Between the 1950s and the 1990s, there were considerable differences among the individual countries of Eastern Europe. The collectivization, specialization, and intensification of agriculture have progressed the most in the former GDR, Czechoslovakia, and Hungary. In these countries, research has focused primarily on an increase in production, and the environmental impact has been more pronounced than in other countries of the Eastern Bloc. It has been, and still is agroecology that deals with this impact. Although both educational and research activities within the framework of agroecology appear even earlier, it is only in the 1990s that their massive development takes place. Due to a lesser emphasis on finding a balance between the organic and production components of agriculture before 1990 compared to Western European countries, it is thus more necessary to implement the principles of agroecology in practice and mitigate the impact of intensive agriculture, which is oriented almost exclusively on economic efficiency. The conservative approach of a significant part of farmers that still hinders their relationship with nature, especially in production areas, and technical, technological, and biotechnological progress has been more focused on the production side of agriculture and its intensification rather than on compatibility with agroecology, although it can be well used to fulfill its principles. It can be assumed that, within conjunction with other outputs in the sphere of biotechnology, biophysics, etc., the importance of agroecology as a scientific field dealing with the balance between production and non-production functions of agroecosystems will grow.

Author Contributions: Jan Moudrý Jr., Jaroslav Bernas; Jan Moudrý sr. and Petr Konvalina-The authors participated in drawing up the introductory chapter Agroecology as a scientific discipline, in drawing up the chapter Agroecology in the Czech Republic and Slovakia, secured collection of agroecology data in the Czech Republic, worked on the assessment of the collected data and on drawing up the part Comparison of agroecology in selected countries of Eastern Europe, and drew up the final part of the paper. Apolka Ujj-The author participated in drawing up the introductory chapter Agroecology as a scientific discipline and the part Comparison of agroecology in selected countries of Eastern Europe, collected data for HU and worked on the chapter Agroecology in Hungary. Ivan Manolov and Atanaska Stoeva-The authors participated in drawing up the part Comparison of agroecology in selected countries of Eastern Europe, collected data for BG and worked on the chapter Agroecology in Bulgaria. Ewa Rembialkowska and Jarosław Stalenga-the authors participated in drawing up the part Comparison of agroecology in selected countries of Eastern Europe, collected data for PL and worked on the chapter Agroecology in Poland. Ion Toncea and Avram Fitiu-The authors collected data for RU and worked on the chapter Agroecology in Romania. Daniel Bucur-The author participated in drawing up the introductory chapter Agroecology as a scientific discipline and the part Comparison of agroecology in selected countries of Eastern Europe, and collected data for RU. Magdalena Lacko-Bartosova and Milan Macák-The authors participated in drawing up the part Comparison of agroecology in selected countries of Eastern Europe, collected data for SK and worked on the chapter Agroecology in the Czech Republic and Slovakia.

Acknowledgments: This work was supported by the University of South Bohemia in České Budějovice research project GAJU 094/2016/Z. 
Conflicts of Interest: The authors declare no conflict of interest. The founding sponsors had no role in the design of the study; in the collection, analyses, or interpretation of data; in the writing of the manuscript, and in the decision to publish the results.

\section{References}

1. Šarapatka, B.; Abrahamova, M.; Cizkova, S.; Dotlacil, L.; Hluchy, M.; Kren, J.; Pokorny, J. Agroekologie: Východiska pro Udržitelné Zemědělské Hospodařeni, 1st ed.; Bioinstitut: Olomouc, Czech Republic, 2010; p. 440.

2. Gliessman, S.R. Agroecology: The Ecology of Sustainable Food Systems, 3rd ed.; CRC Press: Boca Raton, FL, USA, 2014; p. 405, ISBN 9781439895610.

3. Altieri, M.A. Agroecology: The Science of Sustainable Agriculture, 2nd ed.; CRC Press: Boca Raton, FL, USA, 2018; p. 448, ISBN-13 978-0813317182.

4. Migliorini, P.; Galioto, F.; Chiorri, M.; Vazzana, C. An integrated sustainability score based on agro-ecological and socioeconomic indicators. A case study of stockless organic farming in Italy. Agroecol. Sustain. Food Syst. 2018, 1, 1-26. [CrossRef]

5. Altieri, M.A.; Nicholls, C.I. Agroecology and the Search for a Truly Sustainable Agriculture, 1st ed.; United Nations Environment Programme: Mexico City, Mexico, 2005; p. 290, ISBN 9687913355.

6. Křen, J. Systémový prístup k rastlinnej produkci. In Obecná Produdkce Rostlilnná, 1st ed.; Kostelasnký, F., Ed.; MZLU: Brno, Czech Republic, 1997; pp. 32-43.

7. Lacko-Bartošová, M.; Čuboň, J.; Kováč, K.; Kováčik, P.; Macák, M.; Moudrý, J.; Sabo, P. Udržatel'néa Ekologické Pol'nohospodárstvo, 1st ed.; SPU Nitra: Nitra, Slovak Republic, 2005; p. 575, ISBN 80-8069-556-3.

8. Douglass, G.K. (Ed.) The meanings of agricultural sustainability. In Agricultural Sustainability in a Changing World Order, 1st ed.; Westview Press: Boulder, CO, USA, 1984; pp. 3-30, ISBN 0865316694.

9. Harnos, Z. Sustainability. In Conference Proceedings, A System Analytic Approach: Strategies for Sustainable Agriculture, Martonvasar, Hungary, 21-26 September 1992; Győrffy, B., Ed.; BACCE-ARI: London, UK, 1993; pp. 21-26.

10. Glickman, D. Secretary's Memorandum 9500-6: Sustainable Development. U.S. Department of Agriculture, Office of the Secretary, 13 September 1996. Available online: https://www.usda.gov/oce/sustainable/ Council\%20Memorandum.pdf (accessed on 16 February 2018).

11. Fițiu, A. Ecology and Environment Protection, 1st ed.; Academic Press: Cluj-Napoca, Romania, 2003; p. 221, ISBN 9738266947.

12. Ujj, A. A Talajállapot- és az Elővetemény- Hatás Javítása Köztes Védőnövényekkel és Kímélő Mưveléssel. Ph.D. Thesis, Szent Istvan University Gödöllo, Gödöllo, Hungary, 2006.

13. Rovira, A.D. Sustainable farming system in the cereal-livestock areas of the mediterranean region of Australia. In Soil Management in Sustainable Agriculture Proceedings, Third International Conference on Sustainable Agriculture, London, UK, 31 August-4 Swptember 1993; Cook, H.F., Lee, H.C., Eds.; Wye College, University of London: London, UK, 1995; pp. 12-30.

14. Fehér, I.; Madarász, I. European policy context for sustainable agriculture. In Thematic Guide Eight, 8th Summer Academy on Sustainable Agriculture and Rural Development: An Integrated Approach, San Marco Dei Cavoti, Italy, 18-26 July 2009; Apostolides, K., Ed.; Euracademy Association: Athens, Greece, 2009; pp. 38-44.

15. OECD 2008. Environmental Outlook to 2030. Available online: http://www.oecd.org/env/indicatorsmodelling-outlooks / 40200582.pdf (accessed on 8 February 2018).

16. Günal, H.; Korucu, T.; Birkas, M.; Özgöz, E.; Halbac-Cotoara-Zamfir, R. Threats to Sustainability of Soil Functions in Central and Southeast Europe. Sustainability 2015, 7, 2161-2188. [CrossRef]

17. Bruinsma, J. World Agriculture: Towards 2015/2030 an FAO Perspective, 1st ed.; Earthscan Publications: London, UK, 2003; p. 432, ISBN 1844070077.

18. Sansavini, S.; Wollesen, J. The organic farming movement in Europe. HortTechnology 1992, 2, $276-281$.

19. Harwood, R.R. A history of sustainable agriculture. In Sustainable Agricultural Systems, 1st ed.; Edwards, C.A., Lal, R., Madden, P., Miller, R.H., House, G., Eds.; Soil and Water Conservation Society: Ankeny, IA, USA, 1990; pp. 3-19, ISBN 0-935734-21-X.

20. Lampkin, N. Organic Farming, 1st ed.; Farming Press Books: Ipswich, UK, 1990; p. 701.

21. Šarapatka, B.; Niggli, U. Zemědělství a Krajina: Cesty k Vzájemnému Souladu, 1st ed.; Vydavatelství Univerzity Palackého: Olomouc, Czech Republic, 2008; p. 271, ISBN 978-80-244-1885-8. 
22. Carson, R. Silent Spring, 1st ed.; Houghton Mifflin Harcourt: Boston, MA, USA, 2002; p. 368, ISBN-10 0618249060.

23. Conway, G.R. Agroecosystem Analysis for Research and Development; Winrock International Institute for Agricultural Development: Bangkok, Thailand, 1986; p. 111.

24. Altieri, M.A. Agroecology: The Scientific Basic of Alternative Agriculture (Westview Special Studies in Agriculture Science and Policy), 1st ed.; CRC Press: Boca Raton, FL, USA, 1977; p. 227, ISBN-13 978-0813372846.

25. Gliessman, S.R. Agroecology: Researching the Ecological Basis for Sustainable Agriculture; Springer-Verlag: New York, NY, USA, 1990; p. 380. ISBN 978-1-4612-3252-0.

26. Altieri, M.A. Agroecology: The Science of Sustainable Agriculture, 2nd ed.; Westview Press: Boulder, CO, USA, 1995; p. 433, ISBN 1853392952.

27. Gliessman, S.R. Agroecology: The Ecology of Sustainable Food Systems, 2nd ed.; CRC Press: Boca Raton, FL, USA, 2007; p. 384, ISBN 9780849328459.

28. Wezel, A.; Bellon, S.; Doré, T.; Francis, C.; Vallod, D.; David, C. Agroecology as a science, a movement and a practice. In Sustainable Agriculture, 1st ed.; Springer: Dordrecht, The Netherlands, 2011; Volume 2, pp. $27-43$.

29. Buttel, F.H. Envisioning the Future Development of Farming in the USA: Agroecology between Extinction and Multifunctionality. New Directions in Agroecology Research and Education. Available online: http: / /www.dphu.org/uploads/attachements/books/books_2044_0.pdf (accessed on 12 February 2018).

30. Zlatník, A.; Pelikán, J.; Stolina, M. Základy Ekologie, 1st ed.; SZN: Praha, Czech Republic, 1973; p. 281.

31. Andonov, I. Vliv agroekologických podmínek množení na technologickou hodnotu osiva jarního ječmene. Mitt. Hochsch. Landwirtsch. Brno 1976, 24, 51.

32. Kováč, A.; Šimko, J.; Belohorec, R. Študium Tvorby a Redukcie Faktorov Úrodnosti Lucerny Siatej Pestovanej na Hmotu a Semeno v Rôzných Agroekologických Podmienkach, 1st ed.; Záverečná Sprava AF VŠP: Nitra, Czech Republic, 1980; p. 35.

33. Pluhař, J. Effect of Some Agro-Ecological Factors on Occurrence of Disease and Pests in Cereals, 1st ed.; Ústav věDeckotechnických Informací pro ZeměDělství: Praha, Czech Republic, 1983; p. 40.

34. Slavíková, J. Ekologie Rostlin, 1st ed.; SPN: Praha, Czech Republic, 1986; p. 366.

35. Duvigneaud, P. Ekologická Syntéza, 1st ed.; Academia: Praha, Czech Republic, 1988; p. 414.

36. Dykyjová, D. Metody Studia Ekosystémů, 1st ed.; Academia: Praha, Czech Republic, 1989; p. 690.

37. Veverka, K. Zdravotní stav rostlin ve vztahu k výživě a hnojení. In Agroekologie a Výživa Rostlin, 1st ed.; Dům Techniky ČSVTS: Pardubice, Czech Republic, 1990; pp. 23-29.

38. Vergner, I.; Berták, R. Základy Alternationího Zemědělství, 1st ed.; MZe ČR: Praha, Czech Republic, $1991 ;$ p. 101.

39. Petr, J.; Dlouhý, J. Ekologické Zemědělství, 1st ed.; Nakladatelství Brázda: Kyjov, Czech Republic, $1992 ;$ p. 305.

40. Kohout, J.; Škoda, V.; Zitta, M. Obecná Produkce Rostlinná, 1st ed.; Skriptum VŠZ: Praha, Czech Republic, 1993; p. 281. ISBN 80-213-0450-2.

41. Kulich, J. Rizikové Prvky v Agroekologických Podmienkach Hornej Nitry, 1st ed.; Vysoká Škola Pol'nohospodárska: Nitra, Slovak Republic, 1994; p. 106.

42. Barták, M.; Kocourek, F.; Vrabec, V. Obecná Agroekologie, 1st ed.; VŠB-TU Ostrava v Programu PHARE: Ostrava, Czech Republic, 1996; p. 136.

43. Barták, M.; Šarapatka, B.; Kocourek, F. Speciální Agroekologie, 1st ed.; VŠB-TU Ostrava v Programu PHARE: Ostrava, Czech Republic, 1996; p. 179. ISBN 80-7078-353-2.

44. Moldan, B. Indikátory Trvale Udržitelného Rozvoje, 1st ed.; Vysoká Škola Báňská-Technická Univerzita: Ostrava, Czech Republic, 1996; p. 87. ISBN 80-7078-380-X.

45. Remtová, K. Trvale Udržitelný Rozvoj a Strategie Ochrany Životního Prostředí, 1st ed.; Vysoká Škola Báňská-Technická Univerzita: Ostrava, Czech Republic, 1996; p. 95. ISBN 80-85368-93-5.

46. Moudrý, J. Přechod na Ekologický Způsob Hospodaření; Institut Výchovy a Vzdělávání Ministerstva Zemědělství ČR: Praha, Czech Republic, 1997; p. 48, ISBN 80-7105-134-9.

47. Kohák, E. Zelená Svatozářr. Kapitoly z Ekologické Etiky, 1st ed.; Sociologické Nakladatelství (SLON): Praha, Czech Republic, 1998; p. 203.

48. Demo, M.; Bielek, P.; Hronec, O. Trvalo Udržatel'ný Rozvoj: Život v Medziach Únosnej Kapacity Biosféry, 1st ed.; Slovenská Pol'nohospodárska Univerzita: Nitra, Slovakia, 1999; p. 400, ISBN 80-7137-611-6.

49. Dotlačil, L.; Stehno, Z.; Faberová, I. Care on plant genetic resources of agricultural crops in the Czech Republic-Status in 1998. In Plant Genetic Resources-Annual Report 1998, 1st ed.; Slovak Agricultural University: Nitra, Slovakia, 1998; pp. 73-81. 
50. National Society of Conservationists (Magyar Természetvédők Szövetsége). Available online: https:/ / mtvsz. hu/magunkrol (accessed on 12 February 2018).

51. Agrofutura. Available online: http:/ / www.agrofutura.hu/ (accessed on 12 February 2018).

52. Regional Symposium on Agroecology for Sustainable Agriculture and Food Systems in Europe and Central Asia. Available online: http:/ / www.fao.org/europe/news/detail-news/en/c/454802/ (accessed on 12 February 2018).

53. Altieri, M.A. Agroecology: The Scientific Basis of Alternative Agriculture, 1st ed.; Westview Press: Boulder, CO, USA, 1987; p. 246, ISBN 0813372844.

54. Várallyay, G. Agroökológiai-Tájökológiai. Tájökol. Lapok 2005, 3, 1-12.

55. Agro-Ecology Project. Available online: http://nefmi.gov.hu/research/national_projects/nkfp/abstracts/ 3B-0057-2002.html (accessed on 12 February 2018).

56. VAHAVA Project. Available online: https://hu.wikipedia.org/wiki/Vahava-projekt (accessed on 12 February 2018).

57. Dover, M.J.; Talbot, L.M. To Feed the Earth: Agro-Ecology for Sustainable Development, 1st ed.; World Resources Institute: Washington, DC, USA, 1987; p. 88, ISBN 0915825198.

58. Francis, C.; Jordan, N.; Porter, P.; Breland, T.A.; Lieblein, G.; Salomonsson, L.; Sriskandarajah, N.; Wiedenhoeft, M.; DeHann, R.; Braden, I.; et al. Innovative Education in Agroecology: Experiential Learning for a Sustainable Agriculture. Crit. Rev. Plant Sci. 2011, 30, 226-237. [CrossRef]

59. SARE Sustainable Agriculture Research and Education 2010. What Is Sustainable Agriculture? Available online: http:/ / www.sare.org/publications/whatis/whatis.pdf (accessed on 8 February 2018).

60. Francis, C.; Breland, T.A.; Østergaard, E.; Lieblein, G.; Morse, S. Phenomenon-Based Learning in Agroecology: A Prerequisite for Transdisciplinarity and Responsible Action. Agroecol. Sustain. Food Syst. 2012, 37, 60-75. [CrossRef]

61. Sagiter Project. Available online: http:/ / sagiter.eu/wakka.php?wiki=Accueil (accessed on 12 February 2018).

62. Agro Ecological Center of Agricultural University. Available online: http://www.au-plovdiv.bg/centers. php?type $=1 \& i d=16$ (accessed on 30 October 2017).

63. Agroecology Europe. A European association for Agroecology. Available online: http://www.agroecologyeurope.org/ (accessed on 30 October 2017).

64. Agricultural University Plovdiv. Available online: www.au-plovdiv.bg (accessed on 30 October 2017).

65. Ministry of Agriculture, Food and Forestry. Available online: http://www.mzh.government.bg/MZH/en/ Home.aspx (accessed on 30 October 2017).

66. National Agricultural Advisory Service. Available online: http:/ / www.naas.government.bg/en (accessed on 30 October 2017).

67. State Fund Agriculture. Available online: http:/ /www.dfz.bg/en/ (accessed on 30 October 2017).

68. Ministry of Environment and Water. Available online: http://www.moew.government.bg/en/ministry/ (accessed on 30 October 2017).

69. Dimitrov, Y. Ecology and farming. Sci. Works Agric. Univ. 2009, 54, 11-18.

70. Kirechev, D. Agri-evironmental policy in Bulgaria and European Union: Development priorities till 2020. Rep. Union Sci. Varna 2012, 1, 33-43. Available online: http:/ / www.su-varna.org/izdanij/Ikonomika-12/ Pages\%2033-43.pdf (accessed on 30 October 2017).

71. Bioselena. Available online: http:/ / bioselena.com/en (accessed on 30 October 2017).

72. Bulgarian Biodiversity Foundation. Available online: http://bbf.biodiversity.bg/ (accessed on 30 October 2017).

73. Bulgarian Society for the Protection of Birds. Available online: http://bspb.org/ (accessed on 30 October 2017).

74. Association of Agroecological Farm Producers. Available online: http:/ /www.agroecology.bg/ (accessed on 30 October 2017).

75. Association "Ekofarm". Available online: http://aez-ecofarm.zona.bg/information (accessed on 30 October 2017).

76. Sustaining Agricultural Change through Ecological Engineering and Optimal Use of Natural Resources. Available online: http:/ / staccato-project.net/ (accessed on 30 October 2017).

77. Organic Farmers Association of Romania BIOTERRA. Available online: http://www.bioterra.org.ro/ (accessed on 7 December 2017). 
78. Romanian Association for Sustainable Agriculture A.R.A.D. Available online: http://www. agriculturadurabila.ro (accessed on 7 December 2017).

79. National Federation of Ecological Agriculture FNAE. Available online: http://fnae2000.weebly.com/ (accessed on 7 December 2017).

80. Research, Innovation and Technical Assistance Center for Ecological Agriculture of NARDI Fundulea. Available online: http: / www.incda-fundulea.ro/index_en.html (accessed on 7 December 2017).

81. Mihai Eminescu Trust. Available online: http://www.mihaieminescutrust.ro (accessed on 7 December 2017).

82. Eco-Ruralis. Available online: http:/ / www.ecoruralis.ro (accessed on 7 December 2017).

83. Puia, I.; Soran, V. Umanitate și agroecosisteme. Era Soc. 1977, 16, 30-37.

84. Puia, I.; Soran, V.; Klemm, H.; Popescu, V.; Erdelyi, St.; Tatau, V. Elemente de Agroecologie, 1st ed.; Inst. Agr. "dr. P. Groza" Atelierele de Material Didactic: Cluj-Napoca, Romania, 1978; p. 210.

85. Puia, I.; Soran, V. Agroecologie: Ecosistem si Agroecosistem, 1st ed.; Tipo Agronomia: Cluj-Napoca, Romania, 1984; p. 203.

86. Coste, I. Ecologie Agricola, 1st ed.; Institutul Agronomic Timișoara: Timisoara, Romania, 1986.

87. Puia, I.; Soran, V.; Rotar, I. Agroecologie, Ecologism, Ecologizare, 1st ed.; Genesis: Cluj-Napoca, Romania, 1998; p. 265, ISBN 9739387020.

88. Toncea, I.; Alecu, I.N. Ingineria Sistemelor Agricole, 1st ed.; Ceres: Bucuresti, Romania, 1999; p. 85, ISBN 9734004441.

89. IJHARS. 2017. Available online: http://www.ijhar-s.gov.pl/index.php/raporty-i-analizy.html (accessed on 15 February 2018).

90. Permakultura. 2017. Available online: http://permakultura.edu.pl/ (accessed on 15 February 2018).

91. Agroforestry. 2017. Available online: http:// www.agroforestry.pl/ (accessed on 15 February 2018).

92. Ziarno. 2017. Available online: http://www.ziarno.grzybow.pl/ (accessed on 15 February 2018).

93. Juchowo. 2017. Available online: http://www.juchowo.org/ (accessed on 15 February 2018).

(C) 2018 by the authors. Licensee MDPI, Basel, Switzerland. This article is an open access article distributed under the terms and conditions of the Creative Commons Attribution (CC BY) license (http:/ / creativecommons.org/licenses/by/4.0/). 